\title{
Mid-Term Analysis of the Ma Ying-jeou Administration
}

The Difficulty of Delivering the (Right) Goods

\section{Frank Muyard}

\section{OpenEdition \\ Journals}

Édition électronique

URL : http://journals.openedition.org/chinaperspectives/5299

DOI : 10.4000/chinaperspectives.5299

ISSN : 1996-4617

Éditeur

Centre d'étude français sur la Chine contemporaine

Édition imprimée

Date de publication : 15 septembre 2010

ISSN : 2070-3449

Référence électronique

Frank Muyard, " Mid-Term Analysis of the Ma Ying-jeou Administration », China Perspectives [En ligne], 2010/3 | 2010, mis en ligne le 01 septembre 2013, consulté le 28 octobre 2019. URL : http:// journals.openedition.org/chinaperspectives/5299; DOI : 10.4000/chinaperspectives.5299 


\title{
Mid-Term Analysis of the
}

\section{Ma Ying-jeou Administration}

\author{
The Difficulty of Delivering the (Right) Goods
}

FRANK MUYARD

Since his election as Taiwan's president in 2008, Ma Ying-jeou has embarked on an active policy of rapprochement with China, leading to the signing of a string of economic and technical agreements with Beijing that have further liberalised and normalised cross-strait economic relations. But the way this rapprochement has been conducted, coupled with the economic crisis that has struck Taiwan for most of the first two years of Ma's administration and a series of missteps and mismanagements by the president and the Kuomintang (KMT) government, have generated a crisis of confidence and widespread discontent among the Taiwanese. This has resulted in consistently low approval ratings and several setbacks in regional and by-elections in 2009 and 2010, as well as the resurgence of a reformed opposition under the leadership of Tsai Ing-wen. The discrepancy between Ma's increasingly apparent Chinese nationalism and the Taiwan-centred national identity of the majority is further indication of a significant disconnect between the KMT administration and the Taiwanese mainstream.

$\mathrm{T}$ wo years after the large victory by Ma Ying-jeou and the Kuomintang (KMT) in Taiwan's presidential and legislative polls, the new KMT administration and president are facing high levels of discontent among the Taiwanese. Although Ma's honeymoon with the electorate was bound to be short given the numerous economic and political challenges Taiwan was facing in 2008, his dramatic slide in popularity has surprised many observers. ${ }^{(1)}$ The Ma government's rapprochement policy with China has seen some significant results and earned support and applause in most foreign capitals. But the way this policy has been conducted, and a series of missteps and shortcomings by the government and Ma himself, have combined with the global economic crisis to generate a serious crisis of confidence among the public regarding the administration's competence and its ultimate attachment to Taiwan's interests and sovereignty in relation to China. This article will look in greater detail at the first two years of Ma's administration and its policies, their level of success, and the opposition they have encountered. It will address the main challenges faced by the administration: relations with China, the economy, domestic politics and regional elections, and the question of national identity.
The policies and achievements of Ma Ying-jeou and the KMT since 2008

In 2008, the legislative and presidential elections gave the KMT an overwhelming hold on all national political institutions. In the parliament, the KMT and its allies in the Blue camp (the PFP and the NP) won around 55 percent of the vote and more than two-third of the seats of the new 113seats Legislative Yuan (LY), reinforcing their majority and the control of legislative affairs they have exercised continuously in Taiwan since the end of the 1940s. In the presidential poll, the Kuomintang ticket of Ma Ying-jeou and vicepresident Vincent Siew (Hsiao Wan-chang) won decisively, with 58.5 percent against the 41.5 percent for their Democratic Progressive Party (DPP) opponents Frank Hsieh Chang-ting and Su Tseng-chang. ${ }^{(2)}$ Riding the wave of dissatisfaction against the DPP administration and former president Chen Shui-bian, embroiled in corruption scandals and criticised for poor handling of the country's economy, admin-

1. Shelley Rigger, "Ma's Puzzling Midterm Malaise," Brookings Northeast Asia Commentary, no. 37, 11 March 2010.

2. Cf. Frank Muyard, "Taiwan Elections 2008: Ma Ying-jeou's Victory and the KMT's Return to Power," China Perspectives, no. 73, 2008/1, pp. 79-94. 
istrative affairs, and external relations, especially with China and the United States, Ma Ying-jeou led a campaign based on three pillars: reviving the economy, rapprochement with China, and the fight against corruption, together with a strong commitment to Taiwan's sovereignty and identity. His "6-3-3" economic program promised a 6 percent yearly GDP growth, less than 3 percent employment, and a per capita GDP of US\$30,000 by 2016. Ma also advocated closer economic relations with the People's Republic of China (PRC) - presented in pragmatic terms as the best way to improve the Taiwanese economy and the stability in the region - starting with the establishment of the three direct links (air, sea, and postal) between the two sides, and the opening of Taiwan to Chinese tourists and Chinese investment. On the cross-strait political front, Ma announced a policy of "no unification, no independence, and no use of force," with the commitment not to undertake negotiations on unification during his tenure. In domestic affairs, Ma promised a highly efficient and competent administration to reverse the DPP's alleged incompetence and corruption. Finally, he called for a politics of national reconciliation after eight years of partisan polarisation.

\section{Taiwan-China relations}

The rapprochement between Taiwan and China has been at the core of the KMT's national policies since its return to power, and it is here that the most concrete results can be seen. Three aspects of this policy will be analysed here: cross-strait agreements, the Taiwan sovereignty issue, and Taiwan's international space. Although improvements to cross-strait relations were expected with the new administration in power, Ma's government surprised many with the speed and primary focus it put on dealing with Beijing, rather than concentrating on economic revival as declared in his presidential campaign. One reason is that the KMT actually views the future economic development of Taiwan as dependent on its integration within the Chinese economic sphere, while its goal of eventual unification is seen as predicated on an intensification of economic and cultural relations with China. Ma's and the KMT's new China policy therefore advocates a gradual economic, symbolic, and political rapprochement with China with four objectives: lowering political and military tension in the Formosa Strait, strengthening economic ties with China to closely integrate the two economies and eventually form a kind of common market, countering the Taiwanese independence movement, and preparing favourable conditions for a possible unification in a still undetermined future.
In practice, the 20 May 2008 inauguration of Ma as the Republic of China (ROC)'s president was followed rapidly by the resumption of official talks with the PRC through the established channels of semi-governmental entities, the Strait Exchange Foundation (SEF) for Taiwan and the Association for Relations Across the Taiwan Strait (ARATS) for China. Their first meeting in 10 years took place in Beijing in June 2008 and signed off on agreements on direct weekend charter flights and the opening of Taiwan to Chinese tourists coming directly from China. These agreements were largely negotiated and concluded in 2007 by the previous Chen administration, but had been delayed by Beijing to await the KMT's return to power. Since then, "Chiang-Chen meetings" between the SEF and the ARATS have taken place every six months, ${ }^{(3)}$ resulting by the end of 2009 in a total of 12 technical agreements between the two sides on regular direct passenger and cargo flights, sea links, postal service links, Chinese tourists, food safety, crime fighting and judicial mutual assistance, standards and metrology, agricultural product inspection and quarantine, fishing crews, and financial cooperation, as well as three separate financial memoranda of understanding (MOU). ${ }^{(4)}$ Taipei also adopted a series of unilateral measures to facilitate economic relations with China. It has extended access to the direct mini-links (through the Kinmen and Matsu islands), authorised exchange of the PRC currency, the renminbi, in Taiwan, raised the maximum limits of Taiwanese investments in China, authorised Taiwan's mayors and county chiefs to travel in China, relaxed restrictions on Taiwanese investment in foreign funds with Chinese assets, simplified the process of hosting Chinese professional experts in Taiwan, and relaxed rules for initial public offering of foreign companies and for investment by Chinese funds in the Taiwanese Stock Exchange. As a result, the door to China is now open for most Taiwanese high-technology investments as well as banking, insurance, and financial investments, although with some limits in term of the quantity of capital and resources and of the levels of technology poured into Chinese operations to ensure that these companies maintain a strong base in Taiwan. Chinese investments in 100 sectors of the economy are now also allowed for the first time. ${ }^{(5)}$ In May

3. The Chiang-Chen tag refers to the names of the two main negotiators, the chairman of the SEF, Chiang Pin-kun, and the chairman of ARATS, Chen Yunlin.

4. For the details of these cross-strait agreements and their negotiations, as well as the Ma government's current Mainland policies, cf. the websites of Taiwan's Mainland Affairs Council (MAC), http://www.mac.gov.tw/ct.asp?xltem $=67145 \& C+N o d e=$ $5710 \& \mathrm{mp}=1$, and SEF, http://www.sef.org.tw/lp.asp?ctNode=4382\&CtUnit=2567\&Base $\mathrm{DSD}=21 \& \mathrm{mp}=300$.

5. Ting-I Tsai, "In Big Shift, Taiwan Allows Investment From China," Wall Street Journal, 1 July 2009. 
2010, Taipei opened a tourism office in Beijing, followed by the opening of a similar tourism office by the PRC in Taipei, the first quasi-official institutions of either side in the other's territory. ${ }^{(6)}$ Intense negotiations have also been held over a crossstrait economic and free trade agreement under the name ECFA (Economic Cooperation Framework Agreement), which was finally signed at the end of June 2010 (see below). All these agreements signal much-improved relations between Taiwan and China, both economically and politically. Less clear, however, are the concrete benefits of this closer interaction for the majority of the population, which is mainly concerned with economic improvement after two years of stagnation and recession. Furthermore, Ma's China policies are vehemently opposed by the DPP-led Green camp, which criticises the political underpinning of the current cross-strait talks and Ma's "One-China" framework and denounces the risk of over-dependence entailed by a closer economic integration with China. The non-transparent methods employed in Ma's policy of rapprochement, and its ambiguity over the nature of the Taiwanese state, is also a growing source of anxiety among the Taiwanese.

The conclusion of these cross-strait agreements was indeed made possible by mutual acceptance of the so-called " 1992 consensus," ${ }^{(7)}$ Ma's acquiescence to the "One China" principle or a version of it, and avowed rejection of formal independence for Taiwan as a separate state. While rejecting any claim of sovereignty by the PRC over Taiwan, Ma Ying-jeou and the KMT support the view that Taiwan is the ROC, a Chinese independent and sovereign state since its founding in 1912, and as such does not need to reassert its independence. The ambiguity behind these diverging assertions is at the core of the mutual understanding between the two sides that enables them to enter into talks: it assures that both sides officially pursue a "One China policy" and reject the concepts of "Two Chinas" or "One China, One Taiwan" promoted in one form or another by former presidents Lee Teng-hui and Chen Shui-bian, and which better reflect the reality on the ground.

While helpful in dealing with China, this lack of clarity on the status of Taiwan has generated strong opposition in Taiwan, especially after a series of statements by Ma suggesting much deeper Chinese nationalism than he expressed in his presidential campaign. Ma's affirmation of a strong Taiwanese identity and defence of Taiwan's sovereignty and dignity before the 2008 elections did much to appease Taiwanese people's worries about his sense of national belonging, and allowed for the first democratic election of a Mainlander as president of Taiwan. Once in power, however, $\mathrm{Ma}$ and his ministers have constantly emphasised the Republic of China and the belonging of the Taiwanese to the Chinese nation or ethnicity (Zhonghua minzu) at the expense of Taiwan and the Taiwanese identity when referring to the country's name and its "true" national identity. ${ }^{(8)}$ As opposed to the DPP and Lee Teng-hui's KMT, which stated that Taiwan is the ROC and the ROC is Taiwan, Ma Ying-jeou only adheres to the first statement and with an important twist: Taiwan is the ROC now, but only part of it, while the $\mathrm{ROC}$ is not limited to Taiwan and includes mainland China. While this statement mirrors Beijing's definition of the PRC and its claim of territorial sovereignty over Taiwan, this is a radical departure from the consensus gradually formed in Taiwan since 1991, when Lee Teng-hui's government abandoned all claims on mainland China. In an interview with the Mexican daily El Sol in September 2008, Ma stated that both Taiwan and mainland China are "regions" of the ROC under the ROC constitution, a position reiterated since then by the presidential office. For Ma Ying-jeou, relations between Taiwan and China are not state-to-state as they were for Chen Shui-bian (a country on each side of the strait, yi bian yi guo), or "special state-to-state relations" (teshu guo yu guo guanxi) as for Lee Teng-hui, but "special relations between region-to-region on equal-footing" (duideng de diqu dui diqu teshu de guanxi) within the framework of the ROC constitution. ${ }^{(9)}$ This retrogression of

6. "Taiwan Opens Tourism Office in Beijing," United Daily News, 4 May 2010.

7. An expression invented by the former minister of the Taiwanese Mainland Affairs Council (MAC), Su Chi, in February 2000, which contends that in discussions between the SEF and the ARATS in 1992 in Singapore, the two sides agreed to recognise "One China with different interpretations" ( $y i$ zhong ge biao), leading to the signing of the first set of technical agreements between Taiwan and China. Such a "1992 consensus" was however never acknowledged by the Lee Teng-hui administration or by the PRC during the 1990s. On the basis of formal negotiation documents and the advice of Lee Teng-hui, the Chen Shui-bian administration rejected the Su Chi invention. Ma Ying-jeou announced after his electoral victory that his administration would recognise it together with the "One China" principle, with the caveat of different interpretations, meaning that for Taipei the "One China" refers to the Republic of China (ROC). The PRC does not recognise this reading, holding that both sides agreed on "One China" in 1992, and demanding it as a condition for any talks with Taiwan. Su Chi was Ma's National Security Council Chief from May 2008 to February 2010.

8. A polysemic term, minzu can mean nation, nationality, ethnic group, or a national group with no recognised claim to nation-state status (as in shaoshu minzu, the "national minorities" of the PRC). In Taiwan, minzu has a strong ethno-cultural meaning. To translate the idea of nation as a "nation-state," minzu has been replaced in contemporary scholarship by the neologism guozu. Ethnic group is rendered by zuqun. Ethnology is translated by minzuxue. The use of Zhonghua minzu by Ma Ying-jeou reflects the underpinnings of his Chinese nationalism, where the nation is seen in essentialist and culturalist terms based on blood-based filiation and ethnic origins. For Ma, both sides of the Taiwan Strait belong to one Chinese ethnic nation (and all Chinese and Taiwanese, as Ma has said rhetorically several times, are the descendants of the mythical Yellow Emperor) beyond their distinct citizenships, histories, and political trajectories. This is in strong contrast with the way Taiwanese now perceive themselves (see last part of this article).

9. Cf. Ko Shu-ling, "'State To State' Theory is Dead, Ma Says," Taipei Times, 4 September 2008, and Ko Shu-ling, "Ma Refers to China as ROC Territory in Magazine Interview," Taipei Times, 8 October 2008. 
Taiwan to a mere "region" rather than an independent country under the name of the ROC places Taiwan under a Greater China framework, and not only denies the right of self-determination to the Taiwanese but also reduces their identity and sense of specific historical development to a provincial identity and peculiarity within a greater Chinese nation. Compounded by the inability of Ma Ying-jeou to have Chen Yunlin address him as Taiwan's president during his visit to Taiwan for the second Chiang-Chen meeting in December 2008, these statements have generated widespread ill-will among the Taiwanese, even within the Blue camp, regarding Ma, his China policy, and his inability to defend Taiwan's national dignity. The growing assertion of Chinese nationalism by Ma Ying-jeou and his government, in line with the KMT old guard around Lien Chan, Wu Pohsiung, and most of the KMT second-generation mainlander politicians, heralds a return to the KMT's pre-Lee Teng-hui Chinese-centred ideology, which ignores the two past decades of democratisation and Taiwanisation.

All the same, the sensitivity surrounding Taiwan's political status has led Ma to reject any political talks with China up to now. ${ }^{(10)}$ Unhappy with the lack of clarity and progress on this front, Beijing tried to put pressure on $\mathrm{Ma}$ in the fall of 2009, but was obliged to backtrack since Taipei was nowhere near ready to touch upon the issue. ${ }^{(I I)}$ Not only is there no consensus in Taiwan about such talks, but the issue could easily turn into a minefield for the KMT, already suspected of surrendering Taiwan's sovereignty through the string of cross-strait agreements with China and in international affairs. Some limited overtures for a peace agreement and CBM (Confidence Building Measures) were aired but have since been pushed back, and any progress would first need to satisfy Ma's promise not to enter into peace talks without a prior removal of PRC missiles directed at Taiwan. ${ }^{(12)}$

In terms of Taiwan's international space, some progress has been made. As an extension of the understanding over a "One China" principle with Beijing, Ma proposed a "diplomatic truce" and a policy of "mutual non-denial," meaning that both sides should avoid negating the other's existence and refrain from poaching the other's diplomatic allies. ${ }^{(13)}$ Taiwan publicly renounced all forms of checkbook diplomacy, which had been going on for two decades in an intense competition with Beijing, both sides offering developmental aid packages and other perks to foreign countries to maintain or gain diplomatic recognition. In a break with past practice since 1993, the Ma administration has also declined to file an official request for Taiwan's membership in the
UN over the past two years. ${ }^{(14)}$ While justifying this low-profile strategy with the lack of success of previous attempts, the government did not unveil any clear new policy on Taiwan's international space other than to focus on its incremental progress in gaining observer status in UN-related technical organisations.

This truce seems to have been partly respected in practice, albeit not officially recognised, by the PRC. Since 2008, Taiwan has not lost any diplomatic allies (which now number 23, mainly located in Central and South America, Africa, and the Pacific), even though newly elected governments in Paraguay, Nicaragua, and El Salvador had formerly indicated their wish to switch recognition to Beijing. Taiwan was also granted observer status at the WHA (the annual Assembly of the World Health Organization) in May 2009, and again in 2010, a long-time goal of successive administrations in Taipei and the first opportunity for an official, if still restricted, extension of Taiwan's international contacts in a UN-related forum. ${ }^{(15)}$ In the Asia-Pacific Economic Cooperation (APEC), the nomination of former Vice-President and Prime Minister Lien Chan as Taiwan's representative at the 2008 and 2009 APEC head-of-states meeting in Peru and Singapore was hailed in some quarters as progress for Taipei, still barred by Beijing from sending its president or foreign minister. The fact that Beijing favoured the choice of Lien Chan, one of the most pro-China KMT politicians and initiator of the 2005 KMT-PCC anti-Taiwan independence platform, did not, however, dissipate feelings within the Green camp that Ma's efforts to increase Taiwan's diplomatic space remain firmly under Beijing's control. Indeed, apart from the WHA case, which both Taipei and Western countries re-

10. Howard Schneider, "Taiwan's Ma Sets Limits on China Policy," Washington Post, 7 May 2010.

11. "No Consensus on China and Taiwan's '1992 Consensus'," Central News Agency, 14 November 2009; "PRC Draws Bottom Line on Taiwan for KMT," Taiwan News, 17 November 2009. See also Alan Romberg, "The Winter of PRC Discontent," China Leadership Monitor, no. 31, Winter 2010.

12. Cf. "Time Not Ripe for Cross-strait Military CBM Talks," United Daily News, 18 March 2010; "Taiwan to China: Remove Missiles Before Peace Talks," Reuters, 6 April 2010. On the security aspects of the Ma administration's relations with China, cf. Jean-Pierre Cabestan, "The New Détente in the Taiwan Strait and Its Impact on Taiwan's Security and Future, in this issue of China Perspectives.

13. “'Mutual Non-Denial' Remains, Ma Says," Taipei Times, 6 April 2008.

14. "No Bid for Full UN Membership," Taipei Times, 16 August 2008; "No New UN Bid this Year: MOFA," Taipei Times, 13 August 2010.

15. The name and status of Taiwan at the WHA seems, however, to follow Chinese dictates to include it as part of the PRC, and therefore has aroused the strong opposition of the DPP, which sees this as an example of the loss of sovereignty and national dignity implied by Ma's diplomatic policy. Cf. Vincent Y. Chao, "Former Official Laments Nation's Title at WHA," Taipei Times, 6 May 2010. 
garded as a litmus test for the PRC to demonstrate some good-will in return for Ma's overtures and concessions, Beijing has not shown any flexibility or conceded any space, either in discourse or in action, regarding Taiwan's participation in international forums, even smaller ones such as the International Civil Aviation Organization (ICAO) and the UN Framework Convention on Climate Change (UNFCCC). If this situation does not improve, and China does not respond more significantly to the Taiwanese population's requests for better international representation for the island, both Ma and China risk losing all trust from the Taiwanese population on this low-key policy. While the majority of the Taiwanese are in favour of détente in the strait and maintaining the status quo, polls show that they also consistently demand respect for their sovereignty and independence, and yearn for international status and recognition.

Taken as a whole, the political détente in the Taiwan Strait and the signing of technical agreements with Beijing that make business and transportation links with China much easier are important achievements for the Ma administration, and as such have received much support from most foreign capitals. Their possible cost in terms of Taiwan's sovereignty and autonomy, obvious to the opposition in Taiwan, is perceived less clearly abroad, where the main concern is securing a stable and peaceful cross-strait situation, and where the reality and depth of Taiwan's distinct sense of national identity is still far from widely understood. Yet some anxiety about a too-close alignment of Taipei with Beijing was expressed in Tokyo and Washington, and Japan was especially shocked by the expression of a strong anti-Japanese stance by Ma's government after an incident around the Diaoyutai Islands (Senkaku in Japanese) just after the new administration took office. ${ }^{(16)}$ Since then, Taipei has worked harder to reassure its traditional allies that Ma's new embrace of China will not be at the expense of their interests in the region. Taiwan recently signed a major memorandum of understanding to expand cooperation and exchanges with Tokyo to re-launch and improve the traditional close relations between the two countries and their peoples. ${ }^{(17)}$ The Obama administration, for its part, has been supportive of Ma's policies and has allowed him to transit the US several times en route to visiting Taiwan's allies in the Western Hemisphere. Some frictions nevertheless arose following the fiasco created by the Ma government's missteps around the re-authorisation of the sale of US beef in Taiwan, and some important meetings to advance the TIFA negotiations were cancelled. ${ }^{(18)}$
It is of the greatest importance for Taiwan to preserve Washington's support, since the one area where no progress at all has been made in cross-strait relations is the military sphere. Beijing has not only declined to answer Ma's call for removal of its missiles aimed at Taiwan, but has actually increased their number and capacity, as well as the overall military power directed to Taiwan and intended to deter US military assistance to Taiwan in case of an armed conflict in the Formosa Strait. ${ }^{(19)}$ The Obama administration's recent authorisation of arm sales to Taiwan was also received with Beijing's loudest condemnation in years, including a call to boycott US companies and threats of retaliation by China (all directed at Washington without a single criticism addressed to Taipei). Actually, the US arm sale package had already been announced by the former Bush administration and is far from sufficient to redress the military balance in the Strait. As the ensuing months demonstrated, Beijing seemed to have over-shot in this case, and combined with other untimely and unfriendly actions and declarations in various fields of interaction with the West in Winter 2009-2010, it led to an anti-Beijing backlash and growing concern among Western democracies that China's rise would not be as peaceful as it claims. ${ }^{(20)}$ Meanwhile, the military balance of power in the Strait is now tilting decisively toward the PRC, and without new purchases of relatively advanced weapons such as the F-16 C/D requested by Taipei, both Taiwan and the US run the risk of surrendering so much military ground to Beijing that they would be unable to effectively defend the island in the future. ${ }^{(21)}$

\section{Taiwan's economy under Ma}

The economic situation since Ma's arrival in power has been very poor, and has weighed heavily on the public perception of the ability and efficiency of $\mathrm{Ma}$ and his government. Ma

16. "Taiwan Recalls its Japan Envoy over Diaoyutai Islands Clash," China Post, 15 June 2008; I-chung Lai, "Taiwan and the Changing Strategic Balance in the East China Sea," China Brief, vol. 9, no. 24, 3 December 2009.

17. Martin Williams, "Taiwan, Japan Sign Memorandum to Enhance Ties," Kyodo, 30 April 2010.

18. Cf. Ting-I Tsai, "Taiwan Leader Vows to Repair U.S. Ties," Wall Street Journal, 6 January 2010; Alan Romberg, "Weathering the Storm," China Leadership Monitor, no. 30, Fall 2009.

19. Cf. Russell Hsiao, "China-Taiwan Up Missile Ante," China Brief, vol. 10, no. 7, 1 April 2010; Richard Fisher, "The Implications of China's Naval Modernization for the United States," International Assessment and Strategy Center, 11 June 2009, http://www.strategycenter.net/research/publD.199/pub_detail.asp\#.

20. Cf. Alan Romberg, "The Winter of PRC Discontent," op. cit.

21. David A. Shlapak, "Questions of Balance: The Shifting Cross-Strait Balance and Implications for the U.S.," Rand Corporation, CT 343, March 2010. 
was elected on a platform of strong economic growth and economic competence. Both were absent during the first two years of his administration, even before the US and international financial crisis. The Ma government's record now contrasts negatively with the situation he inherited from the DPP. Contrary to the KMT's propaganda depicting a state of economic disaster before the 2008 elections, the Taiwanese economy under the DPP administration was actually doing pretty well in terms of economic growth, exports, technological achievement, product quality, and wealth creation, finishing with a very strong 6.88 percent year-on-year growth in the first quarter 2008, after 5.98 percent in 2007. ${ }^{(22)}$ It had nevertheless been facing for a number of years problems related to growing social inequality, salarybased income stagnation, lower purchasing power, and industrial hollowing out due to the transfer of entire industries to China in search of a better cost-structure. All are deep structural problems that point to a lack of proper wealth distribution and insufficient domestic investment, and call for a difficult overall transformation and upgrading of the economic structure and socio-economic policies. ${ }^{(23)} \mathrm{As}$ the economy is taking off again in 2010, the KMT government will now have to address the very same problems - even more acute since the economic crisis - that dogged the otherwise strong economic performance of the DPP, or risk facing the same rebuttal from the electorate in the next elections.

The impact of the 2007 US subprime crisis on Taiwan started even before the financial meltdown of September 2008, so close are Taiwan's economic links to the US consumer market. ${ }^{(24)}$ The crisis struck Taiwan with full force in the fourth quarter of 2008 , resulting in 0.73 percent growth in 2008 and the worst recession in modern Taiwan history in 2009, although finally relatively constrained on a yearly basis at -1.91 percent thanks to the beginning of a recovery in the fourth quarter. Unemployment jumped to more than 6 percent in mid-2009, its highest level on record, from a low of 3.9 percent in early 2008, while the 2009 per capita GDP fell back to its 2006 level at around US\$17,000. ${ }^{(25)}$ Ma Ying-jeou's government cannot be blamed for the impact of the world recession on Taiwan's economy. Nevertheless, for someone who promised a new economic miracle, his administration was clearly unprepared and showed few results in dealing with the crisis, contrary to all expectations and the KMT's own public discourse. All too focused on its dealings with China, the government did not anticipate the crisis, underestimated it when it struck, and was largely ineffectual in alleviating its effects on the economy. The short-term stimulus measures the government devised were for most part costly and inefficient (e.g., the consumption voucher program), or had unintended negative effects (such as the incentive program for student internships, which depressed entry-level salaries). The massive US\$26 billion four-year spending plan, part of Ma's "12 i-Taiwan projects" economic platform, including US $\$ 15$ billion on infrastructure projects and US\$6 billion to create more competitive industries, was slow to start and largely ineffective due to the usual bureaucratic red tape and rigid budgeting practices. The lack of much-needed public investment in 2008 and 2009 was also, ironically, a result of the KMT-controlled parliament's earlier scorched-earth politics, which blocked or reduced the size of all major infrastructure programs proposed by the DPP administration and regularly cut the budgets of government agencies and ministries for the political showdown before 2008.

The KMT's economic policy is essentially based on a philosophy of opening to China, free trade, tax cuts, and infrastructure development with a strong emphasis on big corporations and high-tech companies. The belief is this will help stimulate production and exports as well as attract investment from foreign and overseas-based Taiwan companies, and lead to higher growth and employment. Major corporate and individual tax cuts were introduced in 2009 and 2010, but without any compensating measures to balance the shortfall in state revenues, leading to growing budget deficits and public debt that are worrying economic experts. ${ }^{(26)}$ Fiscal pressure in Taiwan is now at a record low of 12 percent of GDP and well below that of similarly developed economies. These measures also accentuate income disparity, and oblige the salary-based middle class to bear the brunt of the fiscal pressure while property taxes are undervalued and gains on property and stock transactions are virtually untaxed. ${ }^{(27)}$ Meanwhile, real estate speculation in Taiwan, and especially in the Taipei area, partly fed by offshore capital

22. Cf. Frank Muyard, "Taiwan Elections 2008," op. cit., pp. 89-92. On the 2008-2010 figures, cf. DGBAS, "Key Economic and Social Indicators, July 30, 2010" (figures calculated based on 2006 constant prices), http://eng.stat.gov.tw/lp.asp?CtNode=2191 \&CtUnit $=1050 \&$ BaseDSD $=7 \& \mathrm{mp}=5$.

23. On the Taiwanese economy, cf. Philippe Chevalerias, "The Taiwanese Economy After the Miracle: An Industry in Restructuration, Structural Weaknesses and the Challenge of China, in this issue of China Perspectives.

24. Cf. Peter C.Y. Chow, "The Impact of the Financial Tsunami on Taiwan's Economy," in B. Wakefield (ed.), Taiwan and the Global Economic Storm, Asia Program Special Report, Woodrow Wilson International Center, no.143, October 2009, pp. 5-12.

25. Cf. DGBAS figures, "Key Economic and Social Indicators, 30 July 2010," op. cit.

26. "Stunned by the So-Called Tax Reform," Commercial Times, 20 April 2010; "Auditor Warns of Worsening National Debt Situation," Central News Agency, 28 July 2010.

27. Monique Hou, "Tax System Controversy: Taiwan, 'Island of Inequity'?", CommonWealth Magazine, no. 445, 22 April 2010. 
inflows and large amounts of idle funding, has created a bubble that puts housing out of reach for the middle class. This has added to the strong dissatisfaction against government policies perceived as favouring only the well off. ${ }^{(28)}$

In the past two years, most policies were oriented toward China and Taiwan-China relations rather than toward Taiwan's national economy, its transformation, support of longterm consumption and purchasing power, or export diversification, as Ma's administration seems intent on keeping all its bets on the "magic Chinese bullet." Unfortunately for $\mathrm{Ma}$, this China policy has not delivered much of the promised economic benefits to the population. While the governmentfinanced stimulus in China helped cushion the blow of the global market collapse in 2009, both the value of Taiwanese exports to China and Taiwan's share of Chinese imports declined in 2009, ${ }^{(29)}$ and most of the export recovery unfolding now is linked once again to renewed growth in the US and other developed markets, as well as in all the emerging economies. The projected bonanza of business opportunities to be generated by the direct links and arrival of Chinese tourists did not materialise. The opening of direct flights with China (370 a week by September 2010) and lowering of cross-strait passenger and cargo transportation costs, while welcomed by tourists and Taiwanese doing business in China (Taishang), bring little benefit to the majority who seldom or never visit the mainland. ${ }^{(30)}$ The economic benefit of the arrival of Chinese tourists was largely a mirage in 2008 and most of 2009. Tourists were far fewer than promised and arrived mostly in low-budget tour groups. Numbers for 2010 seem to have finally picked up, and the real economic impact can be better assessed after a few years. Unless their numbers grow exponentially, however, Chinese tourists won't be a major source of revenue for Taiwan, as economists warned from the outset.

Other economic agreements are also clearly directed at big industrial enterprises and financial companies long eager for a larger footprint in China, either for cost reduction or to enter the Chinese market, or both. As two decades of crossstrait economic relations have shown, however, this development has been more beneficial to businessmen, company management, and high-level white-collar workers than to the rest of the population. The continuing flight of Taiwanese industry to the other side of the strait has fully or partially relocated entire sectors of the economy (footwear, toys, leatherwear, electric appliances, small electronics, ceramics, textiles, computers), leaving only in the island the manufacturing of higher-cost and more sophisticated products, and leading to higher unemployment with strong downward pres- sure on salaries. ${ }^{(31)}$ Now the risk is that both traditional and high-tech industries will increasingly relocate their production to China, either as an export base (to the rest of the world or to Taiwan) or to increase their presence on the Chinese market. Recent statistics tend to confirm this trend. In the first half of 2010, the economy showed clear signs of recovery following an upsurge in exports, which are closing in on their highest pre-recession 2008 levels. ${ }^{(2)}$ While the share of Taiwan's China-bound exports keeps rising and reached its highest level ever in April 2010 at 44.2 percent of total exports, half of Taiwanese exports to China are in fact semi-finished goods that are processed and assembled there, mostly in Taiwanese-owned factories, for re-export to developed markets. ${ }^{(33)}$ Indeed, the structure of Taiwanese export orders shows that the proportion of orders for products made by Taiwanese-owned factories in China continues to increase compared with those made in Taiwan, leading to higher revenues for Taiwanese businesses but little benefit to Taiwanese workers. ${ }^{(34)}$

All these issues were central to the debate over ECFA, which turned rapidly into a political contest between the KMT and the DPP, since the ECFA combines the best hopes and worst worries about economic integration and political rapprochement with China. Unable until now to demonstrate the concrete benefits of closer ties with China, Ma's administration is putting all its efforts into the ECFA, which it presents as the only way for Taiwan's emergence from economic "isolation" and irrelevance. According to the government, the ECFA is a limited, non-political trade and investment liberalisation agreement framework that aims for cross-strait tariff reduction, investment guarantees, and protection of intellectual property rights. Its goal is to increase access to the Chinese market for Taiwanese industries and

28. Hsiang-Yi Chang, "What's Fueling Taiwan's Land Price Explosion," CommonWealth Magazine, no. 445, 29 April 2010.

29. "Taiwanese Products Lose Market Share in China in 2009: MOEA," Central News Agency, 30 January 2010.

30. In a 2009 poll, 61.6 percent of respondents said they have never been to China, and 10.1 percent only once, while 12.7 percent of respondents have been there more than five times; cf. "Survey Topic: People's Views on the Chinese Mainland," Want Daily, 11 August 2009, http://www.kmt.org.tw/english/page.aspx?type=article\&mnum=114\& anum $=6703$.

31. Cf. T. J. Cheng, "China-Taiwan Economic Linkage: Between Insulation and Superconductivity," in Nancy Tucker (ed.), Dangerous Straits: The U.S.-Taiwan-China Crisis, New York, Columbia University Press, 2005, pp. 93-130.

32. CEPD, Taiwan's Economic Situation and Outlook, June 2010, http://www.cepd.gov.tw/ encontent/.

33. "Record High Percentage of Taiwan's Exports Sent to China in April," Central News Agency, 7 May 2010; Jonathan Adams, "Weighing the Costs in Asian Trade Talks," New York Times, 12 May 2010.

34. "March Export Orders Hit All-Time High," United Daily News, 21 April 2010. 
services targeted in an "early harvest" list (mainly in the petrochemical, machinery, auto parts, transportation equipment, and financial sectors), ${ }^{(35)}$ to protect Taiwan's economy from the impact of the ASEAN-China FTA that kicked off in 2010 and a future ASEAN+3 (China, Korea, Japan) expected to be in operation by 2011 or 2012, and to help Taiwan sign further FTAs with countries now reluctant to indispose China by entering into trade agreements with the island. The KMT also promised to help sectors of the economy likely to be threatened by the opening of Taiwan to cheaper Chinese products, establishing a 10-year NT\$95 billion (US $\$ 3$ billion) industry-upgrade and welfare fund, with assurances that no additional Chinese agricultural products will be granted access to the island.

The DPP has criticised several aspects of the ECFA. First it denounced the dearth of detailed information about the agreement and the lack of transparency in the negotiations. Secondly, it opposes the over-reliance of Taiwan's economy on the PRC that an ECFA will induce, when Taiwan is already the most economically integrated country with China, and it criticises a hidden unificationist political agenda behind the ECFA. The DPP also denounces the ECFA as benefiting only big business while threatening SMEs and opening the door to more Chinese imports and more industrial outflow to China, combining to create even greater income disparity, unemployment, and social inequality in Taiwan. Critics of the agreement underline that the across-theboard rise of Taiwanese exports in the first half of 2010 shows that Taiwan does not need the ECFA to increase its exports to China and the rest of the world, and that contrary to the government gloom-and-doom predictions, Taiwan is largely impervious to the ASEAN-China FTA, as Taiwan products don't directly compete with ASEAN merchandises in China, or with Chinese products in the ASEAN. They also point to the fact that under WTO rules, such a freetrade framework must lead within 10 years to the abolition of tariffs on more than 90 percent of the trade items between the two sides. ${ }^{(36)}$ The Green camp thus called for holding a referendum on the EFCA on top of full legislative oversight of the agreement, in contrast to previous cursory and automatic LY approval of cross-strait agreements.

While the administration has been at pains to counter these critics and has acknowledged that the ECFA would create both winners and losers (essentially among traditional industries and SMEs), it rejects the need for a referendum and has assured critics that parliament would have the power and opportunity to review and discuss the finalised agreement. After more than a year of intense promotion of the EFCA by the administration, and a TV debate on the subject between Ma Ying-jeou and DPP chairman Tsai Ing-wen in April 2010, polls showed that most Taiwanese did not know or understand its content and that there was no clear majority supporting or opposing the agreement. ${ }^{(37)}$ Even after its signing, an independent poll showed that only 47 percent of the Taiwanese support the agreement, ${ }^{(38)}$ but a majority of people supports holding a referendum on ECFA, even among the Blue camp. ${ }^{(39)}$ After two referendum proposals were rejected on obscure technicalities by the government's Referendum Review Committee in June and August, the Green camp is planning to submit a new proposal this fall. ${ }^{(40)}$ The ECFA was passed by the parliament on 17 August 2010 under the government's favoured wholesale approval instead of an article-by-article vote as requested by the DPP. ${ }^{(4)}$ The agreement is set to go into effect in September 2010, with tariff cuts starting in January 2011. No real economic impact is expected in 2010, and the overall benefits of the agreement are difficult to assess as yet. Research on other FTAs and tariff agreements have shown that all tend to benefit low-cost industries in developing countries and economic elites on all sides, while the lower and middle classes of developed countries suffer the most, and the wealth gap increases. ${ }^{(42)}$ At the same time, if signing the ECFA reduces Beijing's political opposition to more Taiwanese international trade agreements, and leads to more FTAs between Taiwan and its regional economic partners, the EU, and, especially, the US, as promised by Ma's government, the ECFA could be seen as a useful tool for advancing Taiwan's international economic and political interests.

35. For the full text of the ECFA agreement, cf. MAC website, www.mac.gov.tw/ct.asp?xltem= $85781 \& \mathrm{ctNode}=6727 \& \mathrm{mp}=1$; for an analysis of the "early harvest" list and its negotiation, see also Alan Romberg, "Ma at Mid-Term: Challenges for Cross-Strait Relations," China Leadership Monitor, no. 33, Summer 2010.

36. For a critical analysis of ECFA's economic and political aspects, cf. Chen Po-chih (ed.), ECFA: bu neng shuo de mimi? (ECFA: Unspeakable secrets?), Taipei, Taiwan ThinkTank Press, 2010.

37. Cf. TVBS Poll on ECFA Referendum, 31 May 2010. For this and others polls by TVBS cited in this article, cf. www.tvbs.com.tw/news/poll_center/index.html.

38. Global Views Survey Research Center, "Survey on Signed ECFA etc.," 28 July 2010 Unless indicated, for this and other polls by Global Views cited in this article, cf. http://www.gvm.com.tw/gvsrc/eng/index.asp.

39. 55 percent for the overall population, 47 percent among Blue camp supporters. Cf. TVBS Poll on ECFA Referendum, op. cit.

40. "TSU Vows to Go On After Poll is Rejected," Taipei Times, 12 August 2010.

41. "ECFA Receives Legislative Approval," Taipei Times, 18 August 2010. See also Jerome A. Cohen and Yu-Jie Chen, "Taiwan's Leaders Should Welcome Review of Cross-strait Pacts," South China Morning Post, 7 July 2010.

42. "Bracing for Uneven Distribution of Wealth," Commercial Times, 3 May 2010; R. Scott, C. Salas, and B. Campbell, Revisiting NAFTA: Still Not Working for North America's Workers, Economic Policy institute, Briefing Paper 173, 28 September 2006. For the effect on the US economy of the US agreement for permanent NTR for China, cf. Harold Meyerson, "A Marriage Made in China," Washington Post, 18 November 2009. 
On the political side, however, an internal report released in July by the Budget $\mathrm{Centre}$ and the Legal affairs research $\mathrm{Bu}$ reau of Taiwan's Legislative Yuan tends to give credence to the main worries of the opposition by emphasising serious economic and security weaknesses in the ECFA that could lead to an "economic siege" and threaten Taiwan's sovereignty. ${ }^{(43)}$ Confirming the political nature of the ECFA, at least for Beijing, the report highlights the agreement as a key element in China's attempt to achieve unification with Taiwan, and states that Beijing intends to use it as a leverage to increase Taiwan economic dependence on China and apply pressure for political talks on unification.

\section{Administrative performance and public appraisal}

Halfway through his mandate, Ma's inability to deliver on his promises of a quick and strong economic revival, and the realisation by all, including $\mathrm{Ma}$, that his 6-3-3 program is only a distant dream, are eating into Ma's approval and trust rates. His policies of rapprochement with China have also aroused strong opposition within the Green camp and among swing voters. But other important missteps by the president and his government have added to their negative public image and explain their low popularity. Discontent is widespread and not limited to the opposition, with blunt criticism and scathing editorials coming from within the KMT and the pro-Blue media.

The first target of public criticism was a series of crises and their mismanagement by the government since 2008, which unveiled a mixture of incompetence, arrogance, and carelessness among the higher authorities. The debacle of the $\mathrm{Ma}$ government's response to the August 2009 Morakot Typhoon and subsequent flooding (the worst in Taiwan in the past 60 years and leading to more than 600 casualties) was the most egregious example of the administration's inability to react promptly and efficiently to a serious challenge. The crisis was aggravated by the government's apparent lack of concern for the people's problems and opinions, a reluctance to accept international help, and a tendency to evade responsibility for its actions while blaming others for its shortcomings. The government's botched response to some less deadly typhoons and to the scandal of melamine-laced milk from China in the summer of 2008, as well as the full-blown fiasco in the fall of 2009 surrounding the re-authorisation of US beef imports without regard for a past legislative resolution and public concern, are other missteps that have undermined public confidence in the government. The aftermath of the Morakot typhoon forced the resignation of the technocratic Prime Minister Liu Chao-hsuan and a major reshuffle of the cabinet, which is now led by the more down-toearth KMT politician Wu Den-yih. Since then, a series of administrative blunders, contested policies, policy flip-flops, and general disappointment with the KMT administration's performance have kept its public credibility and confidence levels low.

Other reasons for public disappointment include Ma's failure to fulfil his promise of national reconciliation within Taiwan. Instead of reaching out to the opposition and trying to develop consensus on economic and social policies or on China and international policies, $\mathrm{Ma}$ and his administration have been largely deaf to criticism or suggestion, feeding Taiwan's political polarisation and rejecting Green camp members who, after their crushing defeat, would probably have been prepared to discuss national policies. ${ }^{(4)}$ Worse, the Ma administration has been involved in what can only be called a campaign of witch-hunting and revenge against many former DPP government officials through the use of prosecutorial and judicial power against alleged corruption, leading to serious concern among outside observers and judicial experts regarding the behaviour of Taiwan's judicial officials and the political use of justice under the KMT. ${ }^{(4)}$ Former President Chen Shui-bian's trial saga resulted in a sentence of life in prison for corruption (reduced to 20 years on appeal in June 2010) without proof linking him directly to the financial malversations of his entourage, and when the alleged misuse or concealment of political donations were the rules of the game in the legal grey area of Taiwanese political financing. ${ }^{(4)}$ The trial was also marred by a series of dubious actions and decisions by the prosecutors and the judicial system in regards to defence rights and the right to a fair trial. ${ }^{(47)}$ While the general public believes in some degree of

43. Cf. Martin Williams, "Taiwan Legislative Report Warns of Danger in China Trade Deal," Kyodo, 28 July 2010; Flora Wang, "Report from Legislative Agency Details the Crossstrait Political Risk of ECFA," Taipei Times, 29 July 2010. The report is partly based on a May 2010 fact-finding trip and analysis of the China-Hong Kong CEPA free-trade agreement and its consequences on Hong Kong's economy, politics, and press freedom. In June, the opposition accused the KMT of blocking release of the evaluation report to avoid hindering the signing of the ECFA.

44. Julian Baum, "Who's Listening to Taiwan's People?," Far Eastern Economic Review, 6 November 2009

45. "Open Letter on Erosion of Justice in Taiwan," Taipei Times, 6 November 2008; Jerome A. Cohen, "Silence of the Lambs: Taiwan's Top Minds Need to Speak Out on Law Reforms to Help Achieve the Best Democratic Solutions," South China Morning Post, 11 June 2009 .

46. Jonathan Manthorpe, "Evidence Fails to Support Life Sentence for Taiwan's Former President," Vancouver Sun, 16 September 2009.

47. William Lowther, "US Academics Decry Unfair Treatment in Chen Trial," Taipei Times, 28 September 2009. 
culpability by Chen Shui-bian, the way his case and other prosecutions of DPP politicians and former officials were handled by the Ma administration has done a great disservice to Taiwan's society and democracy, and shows how far reform of the judicial system has to go before it reaches the standard shared by more mature democracies. ${ }^{(48)}$ Meanwhile, bills pending in the Ministry of Justice that threaten basic defence and lawyer rights have raised alarm bells within the legal, scholarly, and justice-monitoring communities. ${ }^{(4)}$

Another main concern regarding the administration touches on public and media freedom and overzealous police behaviour. The repressive actions of the police administration before, during, and after public demonstrations or private gatherings criticising the president or the government policies since 2008 - and especially during the demonstrations against the second Chiang-Chen meeting in Taipei in November 2008 - the false reform of the Assembly and $\mathrm{Pa}$ rade Act still used by prosecutors against political and civil rights demonstrators, and other new freedom-restricting laws have angered not only the political opposition but most democratic activists and scholars. ${ }^{(50)}$ In all these cases, bad habits of control and intimidation reminiscent of KMT authoritarian rule have made people wonder whether the freedom and democracy they enjoyed during the Chen years is in danger. ${ }^{(51)}$ On the media front, international press freedom watchdogs have condemned repeated attempts by the $\mathrm{Ma}$ administration to politically control and rein in stateowned media (TV stations, Central News Agency) to support government policies instead of fostering the balanced and critical reporting and analysis that is the duty of free journalism. ${ }^{(52)}$ The purchase of the formerly KMT-controlled China Times media group (including its TV stations) by the China-based and pro-China Taiwanese businessman Tsai Eng-meng has also led to worries that the media industry, already largely in the KMT camp, could fall under the influence of Beijing-linked groups, and that Taiwan's press freedom could deteriorate to the point where self-censorship à la Hong Kong or Singapore and self-congratulating propaganda by powerful pro-government media could undermine the free and public exchange of political and social ideas. ${ }^{(33)}$ As a result, the US-based Freedom House has warned for two years in a row of a decline in press freedom in Taiwan, which has dropped 14 places to the 47th rank in the world, and from first to eighth in Asia since 2008. ${ }^{\left({ }^{54)}\right.}$

All this discontent has been reflected in numerous opinion polls by various survey centres, including pro-KMT media such as the United Daily News, China Times, TVBS, and Global Views Magazine, which show a steady decline in support for $\mathrm{Ma}$ and his administration. According to Global Views polls, Ma Ying-jeou's approval rating fell almost as soon as he was inaugurated, with disapproval jumping to 46.2 percent in June 2008 against 11.9 percent the previous month and exceeding his 37.8 percent approval score. In the past two years, his approval rate remained below 40 percent, and since the Morakot typhoon in August 2009 has hovered between 20 and 30 percent (28.4 percent in June 2010) against a disapproval rate of around 60 percent. The high level of trust with which $\mathrm{Ma}$ entered office at 55.4 percent also dwindled to a low of 38.3 percent in June 2010, with distrust numbers around 43 percent. ${ }^{(55)}$ This shows that dissatisfaction for $\mathrm{Ma}$ is felt across the board, among the Blue camp and swing voters as well as in the opposition Green camp. It also indicates that the crisis of confidence that faces his government is fed not only by economic problems, but also by opposition to his vigorous pro-China policies and disappointment with his administration's performance.

\section{Regional elections and domes- tic political competition}

Not surprisingly, this general dissatisfaction has spilled over into various local elections since 2008. We will first focus on the December 2009 regional elections, and then look into the 10 by-elections held over the last two years to see how the fortunes of the KMT and DPP have changed.

48. Jerome A. Cohen, "A Work in Progress: The Trial of Chen Shui-bian Highlights the Shortcomings of a Legal System in Transition," South China Morning Post, 17 September 2009 .

49. Jerome A. Cohen and Yu-Jie Chen, "Under Threat: Taiwan's Criminal Defense Lawyers and China's," South China Morning Post, 20 January 2010; Celia Llopis-Jepsen, "The Backsliding of Judicial Reform," Taipei Times, 19 January 2010.

50. Cf. "Wild Strawberries Slam Indictment of NTU Professor," Taipei Times, 12 June 2009; Loa lok-sin, "Activists, Academics 'Surrender' to Protest Law," Taipei Times, 14 July 2009; Chiu Hei-Yuan, "The Act that Silences Academics," Taipei Times, 13 July 2009.

51. Cf. Dafydd Fell, "Taiwan's Democracy: Towards a Liberal Democracy or Authoritarianism?," Journal of Current Chinese Affairs, vol. 39, no. 2, 2010, pp. 187-201.

52. Reporters without Borders, "Taiwan: Public Media Independence Threatened, Despite Government Denials," 17 December 2008; William Lowther, "Group Monitoring Taiwan Press," Taipei Times, 6 May 2009.

53. Shelley Shan, "Analysts Wary of China Times Group's Agenda," Taipei Times, 9 May 2009; Ting-I Tsai, "Move to Replace Taiwan Editor Spurs Talk," Wall Street Journal, 11 January 2010.

54. Vincent Y. Chao, "Taiwan's Press Freedoms in Decline, Watchdog Says," Taipei Times, 1 May 2010.

55. Cf. Global Views Survey Research Center, "Survey on President Ma Ying-jeou's Approval Rating," 21 June 2010. TVBS polls present the same trends, with a 19 May 2010 poll showing a 47 percent disapproval rate against only 33 percent approval. 
Table 1. Taiwan 2001-2009 Regional Elections Overall Result (with comparisons for 200917 districts)

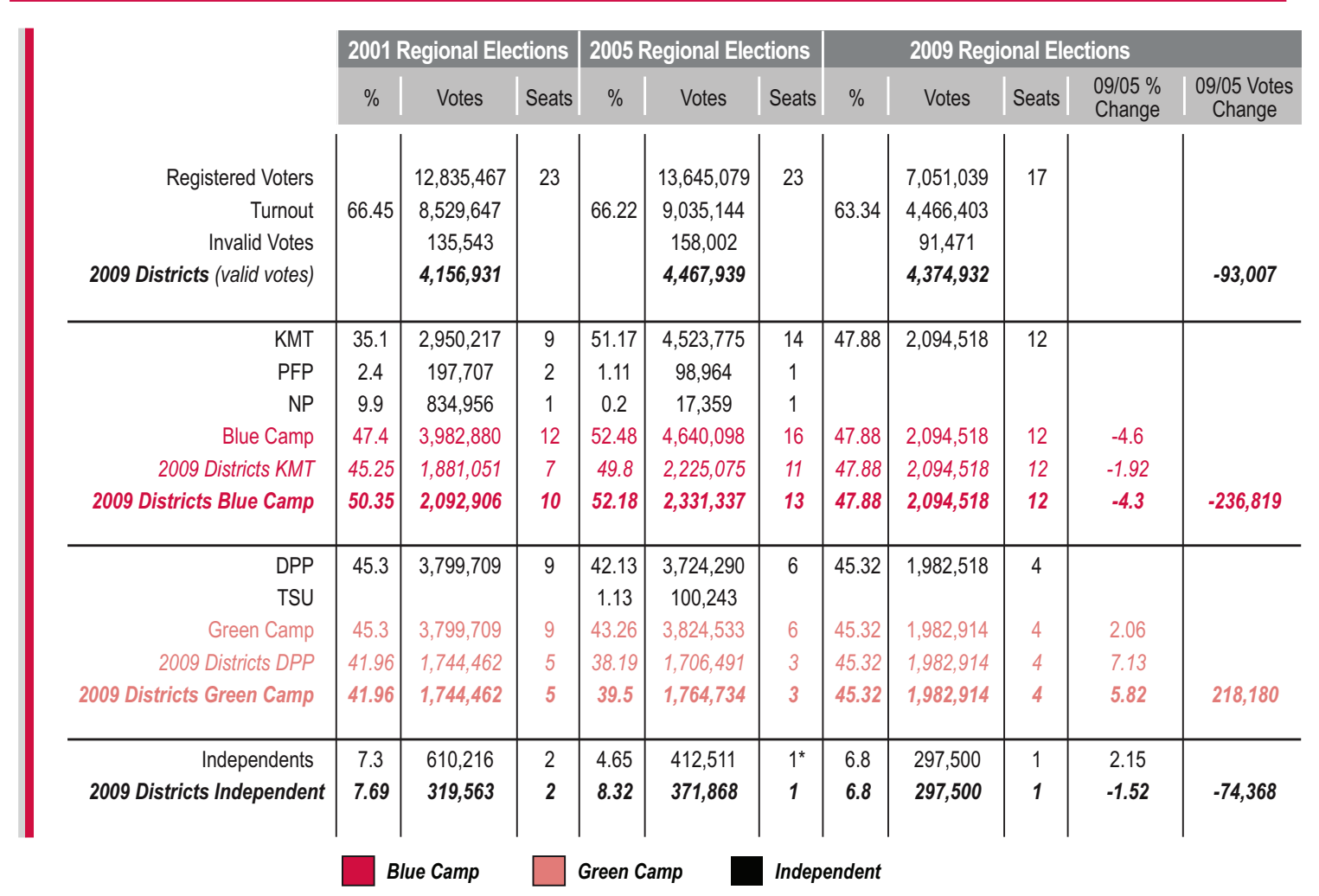

* Elected as an independent candidate, the Taitung County Chief rejoined the KMT after her victory.

Table: Frank Muyard. Source: Central Election Commission

\section{The December 2009 regional elections}

The 16th regional elections for city and county chiefs took place on 5 December 2009 in conjunction with elections for city and county councils and township chiefs in a three-inone format first used in 2005. However, only 17 of the 23 cities and counties in play in 2005 were involved this time, following the government's July 2009 decision to merge and upgrade some cities and counties to the "special municipality" administrative level previously enjoyed only by Taipei and Kaohsiung. As a result, Taiwan now has five special municipalities holding elections for mayors and councillors in November 2010: Taipei City, the new Sinbei City (formerly Taipei County), and the new Taichung, Tainan, and Kaohsiung Cities created by the merging of the former cities and counties of the same names. The electorate of the remaining 17 cities and counties represents only around 40 percent of Taiwan's population. The December 2009 elections were nonetheless politically significant on two counts. First, they provided some indications of the respective strength of the two main political parties and their ability to mobilise their partisans and local networks, especially the KMT, whose electoral machine is particularly strong in local elections. Secondly, although local in nature, they were also the first large-scale and country-wide electoral test faced by both the new KMT administration and a DPP being revamped under Tsai Ing-wen's leadership. ${ }^{(56)}$

The outcome of the elections was an important symbolic success for the DPP and a relative setback for the KMT (see Table 1). Of the 14 cities and counties formerly held by the KMT, one went to the DPP and one to a KMT-dissident independent candidate. While the KMT still won the large majority of seats, the vote numbers and percentages indicated significant progress by the DPP. Compared to the 2005 results (in the same 17 districts), the DPP-led Green camp increased its vote total by 5.82 percent to 45.32 per-

56. The 2009 regional election's overall results cannot be compared directly with the previous elections since different electorates are in play. Tables 1 and 2 therefore also present the reconstructed past results for the 17 cities and counties that were play only in 2009. 
cent, while the KMT-led Blue camp declined by 4.3 percent to 47.88 percent, and the independent vote share dropped 1.52 percent to 6.8 percent. This represents the best results ever for the DPP in regional elections in these districts, while the KMT faced its worst run since 1997 (when a high number of KMT dissident candidates skewed the results and caused the loss of many seats to the DPP). The difference between the two camps has narrowed to only 2.5 percent, a clear success for the Green camp, even if most of the independent votes may be considered pro-Blue. Compared to the 2008 presidential elections in the same districts, the DPP's vote share also increased by 5.8 percent, while the KMT's share plunged 12.63 percent from the 61 percent earned by Ma Ying-jeou.

Analysis of the vote numbers shows the same trends. With a lower turnout and 93,000 fewer valid votes than in 2005, the DPP won more than 218,000 additional votes and the KMT lost more than 236,000 votes, falling back to the level of the whole Blue camp in 2001, while the independents lost 74,000 votes. Perhaps of even greater significance for future elections is the across-the-board increase in DPP votes in traditionally Blue camp regions (see Table 2). Counties that were considered sure bets for the KMT, such as Taoyuan, Taitung, and Penghu, were more contested than expected, with significant progress also recorded in Keelung and Hsinchu City. Meanwhile, DPP incumbents in Yunlin and Pingtung were re-elected with overwhelming majorities exceeding 60 percent and double-digit increases compared to 2005. The combination of lower turnout and DPP progress shows that the KMT failed to mobilise its base while a significant portion of swing-votes went to the DPP. Also symbolically important was the return of long-time Tangwai and DPP-run Ilan County to the DPP fold after four years of KMT administration. Similarly, the loss of strong Blue Hualien County to a former PFP legislator who ran as an independent after being rejected for the KMT nomination over judicial liabilities is a clear personal defeat for the president, who publicly opposed him. ${ }^{(5)}$

On the whole, the DPP also performed better in these elections than in the 23-city and county elections in 2005 ( +2.06 percent). Moreover, the fact that in 2005 the DPP's overall result in the 23 districts was 3.76 percent higher than its results in the 17 districts (in play in 2009) indicates that its vote base is much higher in the 6 districts now merged into or upgraded to special municipalities. One reason is the more rural tint of the 17 districts compared with the more urbanised Taipei, Taichung, Tainan, and Kaohsiung metropolitan areas where the DPP usually scores better, as well as the weight of the southern region of Tainan and Kaohsiung where support for the Green camp is traditionally higher. It is therefore possible that the DPP would have won in terms of vote shares if the regional election had been held in all of the former 23 districts.

Without extrapolating too much on the national significance of such local elections, the December poll results constitute a strong warning message from the electorate to the KMT administration about the way it is ruling the country. The KMT acknowledged this while rejecting any change of orientation in its policies other than improving communication about its work and attending closer to voter needs and interests. The subsequent by-elections indicated that this response failed to change voters' opinions of the ruling party and its government. The DPP for its part regarded the results with cautious optimism as an encouraging but limited success and a welcome boost to confidence following the doldrums of the 2008 defeat. Finally, one must note that the elections were marred by widespread vote-buying, especially by KMT candidates, leading the media to call it one of the dirtiest elections in history, and making the anti-corruption slogans of Ma Ying-jeou sound hollow if not downright hypocritical. ${ }^{(58)}$

\section{9 and 2010 legislative by-elections}

Ten legislative by-elections have been held since 2008, five of them after judicial rulings invalidated the initial polls on the grounds of the vote-buying or ineligibility of KMT candidates (three in 2009: Miaoli, Taipei's Da-an, Yunlin; two in 2010: Taichung County, Taoyuan), and five others to replace legislators elected as city or county chiefs in December 2009 (Chiayi County, Hsinchu County, Hualien, Taitung, Taoyuan). Of those 10 elections, the DPP won seven, including six held in January and February 2010, for a total gain of six seats, confirming its performance in the December regional elections. The DPP candidates beat their KMT opponents not only in pro-Green Chiayi and Yunlin, but also in the two by-elections in Taoyuan, as well as in Taichung, Hsinchu, and Taitung, all counties more

57. For the two other local polls held on December 5, results showed a classic domination by the KMT and independents, although the DPP also increased the numbers of its elected officials. In the election for city and county councils, the KMT received 43.94 percent of the votes, the DPP 24.41 percent, and the independents and other parties 31.65 percent. In the township mayoral elections, the KMT won 121 posts (with 48.82 percent of the votes), the DPP 34 posts (with 20.04 percent), and the independents 56 posts (with 31.14 percent). Source: Central Election Commission.

58. "A Travesty of Democracy," China Post, 7 December 2009; Peter Harmsen, "Vote-buying Taints Taiwan's Democracy: Analysts," Agence France-Presse, 2 December 2009. 
Table 2. Taiwan 2005 and 2009 Regional Elections Results by Districts (2009 Elections's 17 cities and counties only)

\begin{tabular}{|c|c|c|c|c|c|c|c|c|}
\hline \multirow[b]{2}{*}{ Districts } & \multicolumn{4}{|c|}{2005 Regional Elections } & \multicolumn{4}{|c|}{2009 Regional Elections } \\
\hline & $\begin{array}{c}\text { Registered } \\
\text { Voters I } \\
\text { Turnout \% }\end{array}$ & $\begin{array}{c}\text { KMT } \\
\text { (Blue camp) } \\
\text { votes } / \%\end{array}$ & $\begin{array}{c}\text { DPP } \\
\text { (Green camp) } \\
\text { votes } / \%\end{array}$ & $\begin{array}{l}\text { Independent } \\
\text { votes / \% }\end{array}$ & $\begin{array}{l}\text { Registered } \\
\text { Voters I } \\
\text { Turnout \% }\end{array}$ & $\begin{array}{l}\text { KMT (Blue) } \\
\text { votes } / \% / \\
2009 / 2005 \% \\
\text { Change }\end{array}$ & $\begin{array}{c}\text { DPP (Green) } \\
\text { votes / \% / } \\
2009 / 2005 \% \\
\text { Change }\end{array}$ & $\begin{array}{l}\text { Independent } \\
\text { votes / \% }\end{array}$ \\
\hline $\begin{array}{r}\text { Total } \\
\text { (2009 } 17 \text { Districts) }\end{array}$ & & $\begin{array}{c}2,331,337 \\
52.18\end{array}$ & $\begin{array}{c}1,764,734 \\
39.5\end{array}$ & $\begin{array}{c}371,868 \\
8.32\end{array}$ & $\begin{array}{c}7,051,039 \\
63.34\end{array}$ & $\begin{array}{c}2,094,518 \\
47.88 \\
-4.3\end{array}$ & $\begin{array}{c}1,982,518 \\
45.32 \\
5.82\end{array}$ & $\begin{array}{c}297,500 \\
6.8\end{array}$ \\
\hline Ilan & $\begin{array}{c}340,550 \\
70.25\end{array}$ & $\begin{array}{c}121,463 \\
51.39\end{array}$ & $\begin{array}{c}112,853 \\
47.75\end{array}$ & $\begin{array}{c}2,020 \\
0.85\end{array}$ & $\begin{array}{c}351,858 \\
70.68\end{array}$ & $\begin{array}{c}112,469 \\
45.74 \\
-5.65 \\
\end{array}$ & $\begin{array}{c}133,394 \\
54.26 \\
6.51 \\
\end{array}$ & \\
\hline Keelung & $\begin{array}{c}292,330 \\
64.05\end{array}$ & \begin{tabular}{|c|}
$76,162(124,094)$ \\
$41.14(67.04)$
\end{tabular} & $\begin{array}{c}2,771(61,014) \\
1.5(32.96)\end{array}$ & & $\begin{array}{c}299,960 \\
53.04\end{array}$ & \begin{tabular}{r|}
86,001 \\
55.11 \\
-11.93 \\
\end{tabular} & $\begin{array}{c}65,673 \\
42.08 \\
9.12 \\
\end{array}$ & $\begin{array}{r}4,391 \\
2.81\end{array}$ \\
\hline Taoyuan & $\begin{array}{l}1,319,334 \\
61.77\end{array}$ & $\begin{array}{c}488,979 \\
60.84\end{array}$ & $\begin{array}{c}307,965 \\
38.32\end{array}$ & $\begin{array}{c}6,784 \\
0.84\end{array}$ & $\begin{array}{c}1,437,190 \\
53.73\end{array}$ & $\begin{array}{c}396,237 \\
52.22 \\
-8.62 \\
\end{array}$ & $\begin{array}{c}346,678 \\
45.69 \\
7.37 \\
\end{array}$ & $\begin{array}{c}15,807 \\
2.08\end{array}$ \\
\hline Hsinchu City & $\begin{array}{l}277,182 \\
59.6\end{array}$ & $\begin{array}{c}112,221 \\
69.27\end{array}$ & $\begin{array}{c}49,777 \\
30.73\end{array}$ & & $\begin{array}{c}298,439 \\
56.83\end{array}$ & \begin{tabular}{r|}
92,667 \\
55.63 \\
-13.64 \\
\end{tabular} & $\begin{array}{l}68,822 \\
41.32 \\
10.59 \\
\end{array}$ & $\begin{array}{l}5,074 \\
3.05\end{array}$ \\
\hline Hsinchu Co. & $\begin{array}{c}335,906 \\
71.12\end{array}$ & $\begin{array}{c}157,012 \\
67.09\end{array}$ & $\begin{array}{r}77,037 \\
32.91\end{array}$ & & $\begin{array}{c}369,480 \\
69.49\end{array}$ & $\begin{array}{c}97,151 \\
38.49 \\
-28.6 \\
\end{array}$ & $\begin{array}{c}77,126 \\
30.55 \\
2.36\end{array}$ & $\begin{array}{c}78,147 \\
30.96\end{array}$ \\
\hline Miaoli & $\begin{array}{l}411,296 \\
69.45\end{array}$ & $\begin{array}{c}134,277 \\
47.91\end{array}$ & $\begin{array}{r}83,694 \\
29.86\end{array}$ & $\begin{array}{c}62,313 \\
22.23\end{array}$ & $\begin{array}{c}425,837 \\
68.28\end{array}$ & $\begin{array}{c}181,256 \\
63.79 \\
15.88 \\
\end{array}$ & $\begin{array}{c}95,469 \\
33.6 \\
3.74 \\
\end{array}$ & $\begin{array}{c}7,413 \\
2.61\end{array}$ \\
\hline Changhua & $\begin{array}{c}961,048 \\
71.16\end{array}$ & $\begin{array}{c}370,790 \\
55.46\end{array}$ & $\begin{array}{c}270,949 \\
40.52\end{array}$ & $\begin{array}{c}26,887 \\
4.02\end{array}$ & $\begin{array}{c}991,741 \\
65.56\end{array}$ & $\begin{array}{c}348,341 \\
54.89 \\
-0.57 \\
\end{array}$ & $\begin{array}{c}276,897 \\
43.63 \\
3.11 \\
\end{array}$ & $\begin{array}{c}9,402 \\
1.48\end{array}$ \\
\hline Nantou & $\begin{array}{c}398,903 \\
70.48\end{array}$ & $\begin{array}{c}124,777 \\
45.32\end{array}$ & $\begin{array}{c}83,503 \\
30.33\end{array}$ & $\begin{array}{l}67,064 \\
24.36\end{array}$ & $\begin{array}{c}408,006 \\
67.75\end{array}$ & $\begin{array}{c}136,951 \\
50.87 \\
5.55 \\
\end{array}$ & $\begin{array}{c}107,023 \\
39.75 \\
15.39 \\
\end{array}$ & $\begin{array}{c}25,243 \\
9.37\end{array}$ \\
\hline Yunlin & $\begin{array}{c}553,486 \\
69.73\end{array}$ & $\begin{array}{c}167,690 \\
44.48\end{array}$ & $\begin{array}{c}201,192 \\
53.37\end{array}$ & $\begin{array}{c}8,125 \\
2.16\end{array}$ & $\begin{array}{c}560,207 \\
64.61\end{array}$ & $\begin{array}{c}121,832 \\
34.63 \\
-9.85 \\
\end{array}$ & $\begin{array}{c}229,958 \\
65.37 \\
12 \\
\end{array}$ & \\
\hline Chiayi City & $\begin{array}{c}196,054 \\
70.77\end{array}$ & $\begin{array}{c}74,786 \\
54.63\end{array}$ & $\begin{array}{c}62,122 \\
45.37\end{array}$ & & $\begin{array}{c}202,581 \\
66.96\end{array}$ & $\begin{array}{c}69,962 \\
52.2 \\
-2.43 \\
\end{array}$ & $\begin{array}{c}61,268 \\
45.71 \\
0.34 \\
\end{array}$ & $\begin{array}{r}2,801 \\
2.09\end{array}$ \\
\hline Chiayi County & $\begin{array}{c}422,387 \\
71.64\end{array}$ & $\begin{array}{c}109,192 \\
37.31\end{array}$ & $\begin{array}{c}183,476 \\
62.69\end{array}$ & & $\begin{array}{c}428,673 \\
75.29\end{array}$ & $\begin{array}{c}128,973 \\
40.67 \\
3.36 \\
\end{array}$ & $\begin{array}{c}177,333 \\
55.92 \\
-6.77 \\
\end{array}$ & $\begin{array}{c}10,829 \\
3.42\end{array}$ \\
\hline Pingtung & $\begin{array}{c}672,781 \\
70.68\end{array}$ & $\begin{array}{c}195,928 \\
41.86\end{array}$ & $\begin{array}{c}216,200 \\
46.19\end{array}$ & $\begin{array}{l}55,980 \\
11.96\end{array}$ & $\begin{array}{c}682,475 \\
68.09\end{array}$ & $\begin{array}{c}185,384 \\
40.67 \\
-1.19 \\
\end{array}$ & $\begin{array}{c}270,402 \\
59.33 \\
13.14 \\
\end{array}$ & \\
\hline Hualien & $\begin{array}{c}258,736 \\
61.6\end{array}$ & $\begin{array}{c}66,575(104,954) \\
42.66(67.25)\end{array}$ & $\begin{array}{c}30,988 \\
19.86\end{array}$ & $\begin{array}{c}20,113 \\
12.89\end{array}$ & $\begin{array}{c}261,214 \\
59.47\end{array}$ & $\begin{array}{c}38,603 \\
25.44 \\
-41.81\end{array}$ & & $\begin{array}{c}113,127(85,532) \\
74.56(56.37) \\
43.48\end{array}$ \\
\hline Taitung & $\begin{array}{c}178,785 \\
60.51\end{array}$ & & & $\begin{array}{c}105,080(62,189) \\
100(59.18)\end{array}$ & $\begin{array}{c}178,139 \\
61.88\end{array}$ & $\begin{array}{c}56,354 \\
52.59\end{array}$ & $\begin{array}{l}50,802 \\
47.41\end{array}$ & \\
\hline Penghu & $\begin{array}{l}70,427 \\
72.16\end{array}$ & $\begin{array}{c}25,223 \\
50.69\end{array}$ & $\begin{array}{c}23,964 \\
48.16\end{array}$ & $\begin{array}{l}572 \\
1.15\end{array}$ & $\begin{array}{c}75,033 \\
63.33\end{array}$ & $\begin{array}{c}22,664 \\
49.37 \\
-1.32 \\
\end{array}$ & $\begin{array}{c}22,069 \\
48.07 \\
-0.09\end{array}$ & $\begin{array}{l}1.177 \\
2.56\end{array}$ \\
\hline Kinmen & $\begin{array}{l}52,039 \\
62.78\end{array}$ & $\begin{array}{l}(17,359) \\
(54.28)\end{array}$ & & $\begin{array}{l}14,622 \\
45.72\end{array}$ & $\begin{array}{c}72,509 \\
53.8\end{array}$ & $\begin{array}{l}14,269 \\
37.28\end{array}$ & & $\begin{array}{l}24,011 \\
62,72\end{array}$ \\
\hline Lienchiang & $\begin{array}{l}8,170 \\
60.99\end{array}$ & $\begin{array}{l}(2,592) \\
(52.9)\end{array}$ & & $\begin{array}{c}2,308 \\
47.1\end{array}$ & $\begin{array}{r}7,697 \\
72.25\end{array}$ & $\begin{array}{l}3,135(5,404) \\
57.19(98.58)\end{array}$ & & $\begin{array}{c}78 \\
1.42\end{array}$ \\
\hline
\end{tabular}

Winners in bold type and red, light red, or black according to political affiliation. 2005/2009 percentage change for Blue and Green camps only. Table: Frank Muyard. Source: Central Election Commission 
favourable to the Blue-camp. Meanwhile the Miaoli by-election was won by a DPP-supported KMT dissident candidate, leaving only two lukewarm victories for the KMT in the Blue bastions of Taipei's Da-an district and Hualien.

As a result, the KMT's majority in the Legislative Yuan decreased from 81 to 74 seats, while the number of DPP legislators rose from 27 to 33 . With its independent allies, the KMT still controls up to 78 seats, ${ }^{(59)}$ a comfortable majority that enables it to pass any legislation it wishes, at least when bad communication between the KMT government and the KMT legislative caucus does not hinder the approval of administration policies and budgets as during the US beef authorisation fiasco and other cases of disagreement between the two branches of government in the past two years.

\section{The DPP resurgence}

Along with Ma's declining popularity, the political landscape of the past two years has been marked by a gradual resurgence of the DPP as attested by its recent electoral successes. This has been fuelled by the electorate's disappointment with the KMT and the DPP's changing leadership and discourse. Since the crushing electoral defeats of 2008, the DPP has embarked on a double policy of reform and rebuilding to consolidate core support and expand into the crucial swing voter segment of the population. The new direction under Tsai Ing-wen's chairmanship has gradually dissociated the party from Chen Shui-bian and the corruption scandals surrounding his family while still defending the achievements of the DPP's eight-year administration in terms of economic growth, promotion of Taiwan's sovereignty and identity, and social policies. In doing so, the party has been careful not to be seen as letting down the former president, who still commands sympathy and support among deep-Green partisans who see his prosecution as a political vendetta by the KMT. At the same time, the new leadership has attempted to make the party more policy-oriented, with technical expertise and competence in devising policies beneficial to the whole population, especially the middle and working classes. It also promotes the records of city and county governments under DPP rule to bolster the image of a party close to the population and with good administrative governance. This has worked well with Tsai Ing-wen's academic background and expert image and has helped mitigate the radical image too often associated with the DPP under Chen Shui-bian. Occasional clashes during street demonstrations and brawls in the Legislative Yuan still hinder a wholesale revamping of the party image. But they also attest to the intense frustration and anger felt by Green camp supporters regarding the direction the country is taking and their feeling of powerlessness in influencing its course. Following its recent election successes, the DPP is in better shape in terms of unity and self-confidence. Opinion polls also show that since November 2009, Tsai Ing-wen has enjoyed a higher approval rating than Ma Ying-jeou, ${ }^{\left({ }^{(6)}\right)}$ and the party will also certainly continue to benefit from any mistakes and failures by the government and the KMT. But winning future national elections will require reshaping itself into a party more focused on bread-and-butter issues and proposing clear and (maybe more) pragmatic policies regarding Taiwan's relations with China and the issue of independence to attract greater support from middle-of-the-road voters.

The next major electoral test will be on 27 November 2010 with the election of mayors and city councils in the five special municipalities. The DPP can count on the achievements of its local magistrates in the former Kaohsiung and Tainan cities and counties, which coupled with traditional higher support in the south will put the party in the driver's seat for these two new southern municipalities if it can avoid internal divisions. The battle for Taipei, Sinbei, and Taichung special municipalities, in more Blue-leaning regions, will depend on the quality of the DPP and KMT candidates, the internal unity of the two camps, and the overall record of the local and central KMT governments. ${ }^{(6)}$ For the KMT, victory in these three municipalities is essential to show that it can end its decline and put itself in position for the 2012 elections.

There is still a long way to go before the 2012 legislative and presidential elections, and many things can happen in the volatile Taiwanese political climate. The main change, however, is that Ma Ying-jeou's re-election is no longer assured. Spring 2010 polls indicated that Ma could loose the election in the case of a Su Tseng-chang candidacy. ${ }^{(62)}$ In 2008, a second-term was considered a sure bet by both the KMT and the opposition. That this is no longer the case demonstrates how much the KMT and Ma Ying-jeou's policies and performance have disappointed the population. The 2012

59. In July 2010, another Blue camp legislator and sole PFP representative (representing the "Plains aborigines") had his election annulled for vote buying.

60. Cf. Global Views Survey Research Center, "Taiwan Public Mood Index June 2010," 25 June 2010.

61. By June 2010, all the candidates were chosen. They are: in Taipei, Hau Lung-bin (KMT) vs. Su Tseng-chang (DPP); in Sinbei, Eric Chu Li-luan (KMT) vs. Tsai Ing-wen (DPP); in Taichung, Jason Hu Chih-chiang (KMT) vs. Su Jia-chyuan (DPP); in Tainan, Kuo Tien-tsai (KMT) vs. William Lai Ching-te (DPP); and in Kaohsiung, Huang Chao-shun (KMT) vs. Chen Chu (DPP).

62. "Public Opinion Poll. Survey Topic: 2012 Presidential Election," United Daily News, 19 March 2010, http://udn.com/NEWS/NATIONAL/NAT1/5484850.shtml. 
election is still Ma's to lose, as he will have the advantages of incumbency and government and KMT networks, money, and media power. Even so, his re-election will depend on marked improvement to the economy and evidence that the administration is noting and addressing public concerns and needs. Ma may also have to tread more cautiously on the issues of relations with China and Taiwan's sovereignty in acknowledgement of a growing gap between his administration and the rest of the population in terms of national identity.

\section{Ma Ying-jeou and Taiwan's national identity}

Ma was not elected on a Chinese reunification or Chinese nationalist program. On the contrary, he launched a campaign centred on his own Taiwanese identity, the defence of Taiwan's sovereignty as the Republic of China, and his commitment that Taiwan's future must be decided only by the 23 million Taiwanese. ${ }^{(63)}$ What is worrisome for many Taiwanese, over and above the 41.5 percent who voted against $\mathrm{Ma}$, is the disappearance of Ma's Taiwan-centred discourse and its replacement by a Chinese nationalist discourse focusing on the Republic of China and the great Chinese ethnicity/nation (Zhonghua minzu). A new awareness of Ma's personal Chinese nationalism is also attested in polls of public perceptions of Ma's stance on the unification-independence issue. ${ }^{(64)}$ While August 2005 found 46.9 percent of the respondents believing that Ma's stance was to keep the status quo, against 24 percent who believed he was leaning towards unification, in October 2009 only 30.1 percent still believed that Ma supported the status quo option in the long term, against 45.1 percent who thought he favoured unification.

A major problem with Ma's pro-Chinese rhetoric, apart from its shift away from his election discourse, is that it goes against the evolving Taiwanese identity and the public perception of China. Opinion polls results even seem to indicate that the more the KMT government leans toward China and cosies up to PRC officials, and the more the Taiwanese meet Chinese people, the greater the public identifies as Taiwanese and as different from the Chinese. After the return to power of the KMT in 2008, some in Taiwan and abroad expected the rise of Taiwanese national identity and nationalism to stop or recede. This was especially the case among those who attributed these phenomena mainly to political manipulation by the former administrations of Lee Teng-hui and Chen Shui-bian. Others believed that under a new pro-China government, growing economic inte- gration between Taiwan and China would morph into the rise of a "common" Chinese identity and a desire for political unification among the Taiwanese. All surveys since 2008 indicate that this is not the case, however, and that Taiwanese identity and opposition to unification have reached their highest level ever under Ma's rule, especially among the young generation.

According to the NCCU Election Survey Center's polls, the number of respondents identifying as Taiwanese in December 2007 was 43.7 percent, against 44.5 percent who perceived themselves as both Taiwanese and Chinese and 5.4 percent as Chinese. ${ }^{(65)}$ In June 2008, it was respectively 46.1 percent against 45.4 percent and 3.4 percent. In June 2010, 52.4 percent of the respondents said they were Taiwanese - a jump of 6.3 percent in two years - against 40.4 percent with dual identity and only 3.8 percent Chinese. The steady rise in the number of Taiwanese identifiers at the expense of both Chinese identity and dual identity continued, therefore, even after Ma's 2008 victory, leading the Taiwanese identity group to constitute the majority of respondents since December 2008, and to register the highest score ever for any category in June 2010. Concurrent polls by the Blue-leaning TVBS media group confirm this trend, and show that when asked to choose between only two options, 72 percent of the respondents identified as Taiwanese against 16 percent as Chinese in March 2009, a rise of 4 percent and a decline of 2 percent, respectively, since June 2008. ${ }^{\left({ }^{66)}\right.}$ A more recent comprehensive poll by CommonWealth Magazine also indicates that in December 2009, 62 percent of respondents said they were Taiwanese, against 22 percent as both Taiwanese and Chinese, and 8 percent as Chinese. ${ }^{\left({ }^{(6)}\right)}$ The trend is even more accentuated among the young: 75 percent in the 18-29 age group perceive themselves as Taiwanese, against 14 percent as Taiwanese and Chinese and 7 percent as Chinese.

On the independence/unification issue, polls also show a clear trend against unification and in favour of separateness if not outright Taiwanese independence. While the status

63. Cf. F. Muyard, "Taiwan Elections 2008," op. cit.; Daniel Lynch, "Mr. Ma's Taiwanese Identity," Far Eastern Economic Review, vol. 171, no. 2, March 2008.

64. Cf. Global Views Survey Research Center, "Survey on President Ma Ying-jeou's Performance after Assuming KMT Chairpersonship etc." 22 0ctober 2009, www.taiwansecurity.org/2009/GVMaApproval_Independence-102209.pdf.

65. Cf. "Important Political Attitude Trend Distribution," June 2010, Election Study Center, National Chengchi University, http://esc.nccu.edu.tw/english/modules/tinyd2/ index.php?id=6.

66. Cf. TVBS Public Opinion Poll, 12 March 2009

67. Cf. "2010 State of the Nation Survey," CommonWealth Magazine, no. 437, 15 December 2009. http://english. cw.com.tw/article.do?action=show\&id=11589. 
quo option always wins the greatest support in all polls, when asked more specifically about a choice between independence and unification, respondents are overwhelmingly in favour of the former. TVBS polls show that in December 2009, 68 percent of Taiwanese supported independence against 13 percent for unification, with 19 percent expressing no opinion. This marked a rise of 13 percent for independence and a decline of 12 percent for unification since March 2007. ${ }^{(68)}$ Another series of polls by Global Views Magazine indicates that in July 2010, 66.1 percent of Taiwanese opposed unification with China even if the two sides had a similar level of political and economic development, against 12.1 percent who agreed to it. ${ }^{(69)}$ The rejection of unification is therefore based on more than a preference for democracy and free society against dictatorship. It also clearly reflects a perception of two different societies and the desire to maintain a separate country from China.

As a whole, Taiwanese have a rather pragmatic and business-like attitude towards China. In 2009, 52.3 percent considered "people on the mainland" as business partners against 13.3 percent who saw them as friends. ${ }^{(70)}$ When asked about the reason for any future travel to China, 73.2 percent of Taiwanese respondents said tourism, followed by only 14.5 percent for work or business, and 3.5 percent to visit family and friends. Taiwanese also express increasingly negative views of China and the Chinese. According to a September 2009 CommonWealth poll, this is not the result of ignorance but rather of increased contact: the more experience people have of China, the greater their scepticism or fear of it. ${ }^{(71)}$ This poll also indicates that 70 percent of Taiwanese have a negative opinion of Chinese tourists, while another 70 percent fear that cross-strait exchanges may harm Taiwan's sovereignty, 75 percent are afraid that closer interactions with China will threaten their job or livelihood, and 60 percent believe that the new cross-strait relations mostly benefit the KMT and the CCP. This does not mean that Taiwanese oppose cross-strait exchange relations, but they are divided over the benefits (48 percent believing they are largely beneficial against 43 percent who believe that negatives outweigh positives), and are clearly afraid that economic rapprochement with China and current pro-China policies may be against their interests.

All poll results since Ma Ying-jeou's presidential victory indicate, therefore, that the change of government has not reversed long-time trends in Taiwan's national identity. As opposed to the KMT's dictatorship era, since the 1990s Taiwanese have been free to choose and express their national identity and have manifested an increasingly clear choice for preserving the separation between China and the inclusive Taiwanese society and nation most of them feel they now share, even in the case of similar economic and political conditions in the future. Since the turn of the 1990s, changes in Taiwanese society have also followed a path that diverges from China's. While some thought that trade and capitalism would bring the two societies closer, they have in fact moved even further away from each other with Taiwan's democratisation and generational replacement. While the large number of Taiwanese working in China has resulted in growing contact between the populations of the two countries, this has not necessarily brought Taiwanese closer to the Chinese or involved them in the same life community. Rather, it has resulted in greater awareness of the differences between the societies: lifestyle, education, behavioural habits, interpersonal relationships, open-mindedness, appreciation of cultures and foreign countries (especially United States and Japan), social security and health systems, and rule of law, on top of political freedom and democracy. Increased contact with the Chinese, either in the PRC for business and tourism, or in Taiwan with the growing number of Chinese tourists, seems to feed the same sense of distinctiveness that occurred when visits to China were first allowed at the end of the 1980s. Ma's policies of rapprochement with China also appear to have generated an even stronger desire among the Taiwanese to assert Taiwanese identity and their desire for independence.

\section{Conclusion}

In term of national identity, Ma and most of the KMT's other older-generation politicians, especially with Mainlander backgrounds, now find themselves out of step and in a deep disconnect with the rest of the population, native Taiwanese, Aborigines, and the younger Mainlander generation alike. ${ }^{(72)}$ This gap is one reason for the Ma administra-

68. TVBS Public Opinion Poll, 13 March 2009, op. cit., and TVBS Public Opinion Poll 17 December 2009

69. Global Views Survey Research Center, "Survey on Signed ECFA etc.," op. cit.

70. On the opposite side, 53.3 percent of the Chinese surveyed regarded the "people on Taiwan" as family and relatives, and only 16.2 percent as business partners. Cf. Globa Views Research Center, "Survey on How Each Side of Taiwan Strait Views the Other," 1 July 2009, www.kmt.org.w/english/page/aspx?type=article\&mnum=114\&anum= 6489

71. Jerry Lai, "Survey on Cross-strait Relations: Three out of Four Taiwanese Have Sinophobia," CommonWealth Magazine, no. 430, 10 September 2009, http://english.cw.com.tw/article.do?action=show\&id=11340.

72. According to the latest survey on Taiwan's ethnic repartition, Mainlanders compose around 9 percent of the overall population, Hoklo 70 percent, Hakka 14 percent, Aborigines 2 percent and "Taiwanese" 4 percent. Cf. Council for Hakka Affairs, Executive Yuan, "Research Report on 2008 National Research Survey on Hakka Population," Council for Hakka Affairs Press, December 2008, p. 71. 
tion's problems and loss of trust among the Taiwanese. It also shows that $\mathrm{Ma}$ and his administration do not understand or are unwilling to accept Taiwan's changing political and national identity over the past two decades. The election of Ma Ying-jeou as president of Taiwan showed that the Taiwanese want to benefit more from China's economic growth and desire peaceful relations with China, as promised by Ma's campaign. At the same time, they continue to assert their independence, their sovereignty, and their Taiwanese national identity. The capacity of Ma and the KMT to recognise this reality and to start representing the identity of the majority of the population instead of denying it under a Chinese ethnic discourse will be one of the factors in play in the next election. Together with the country's socio-economic performance and the administrative competence of his government, it will determine whether Ma can win a second term, or if the DPP will have another shot at ruling the country. $\bullet^{\bullet}$

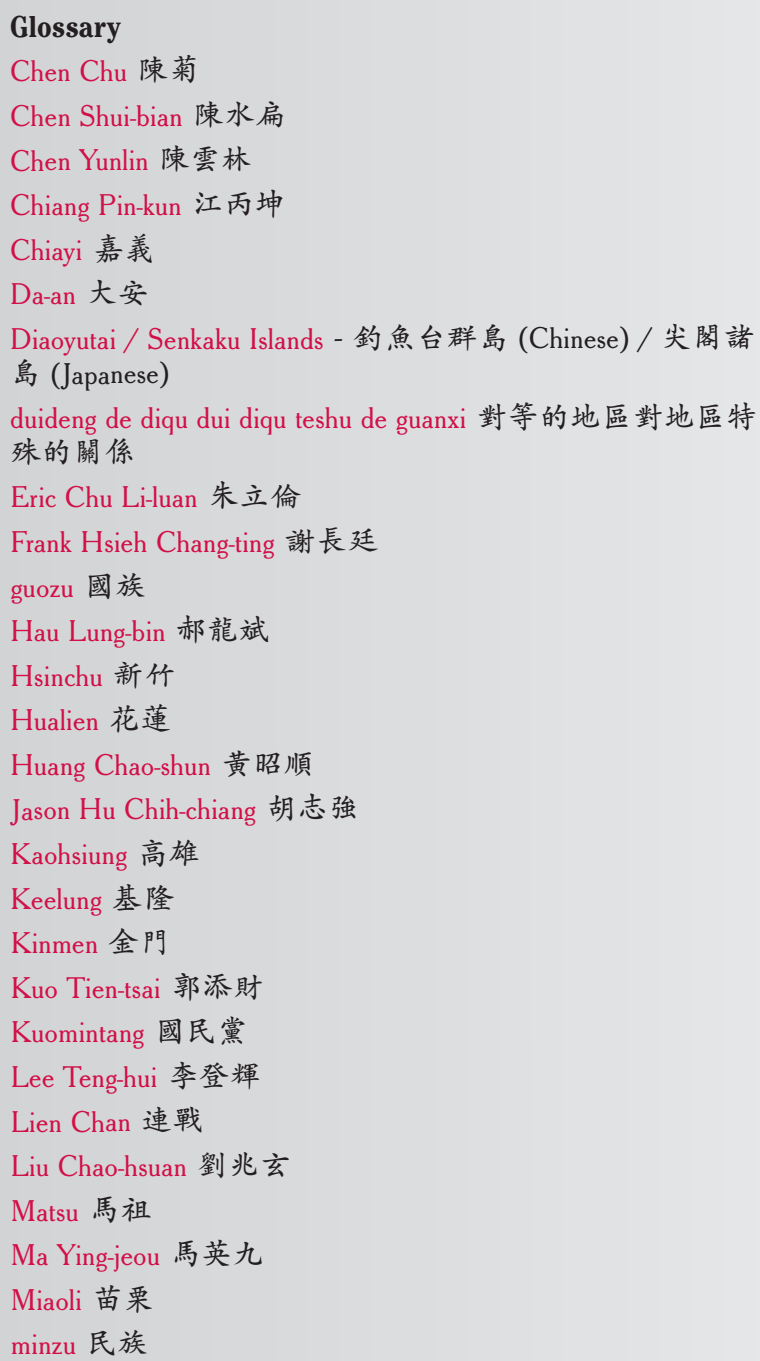

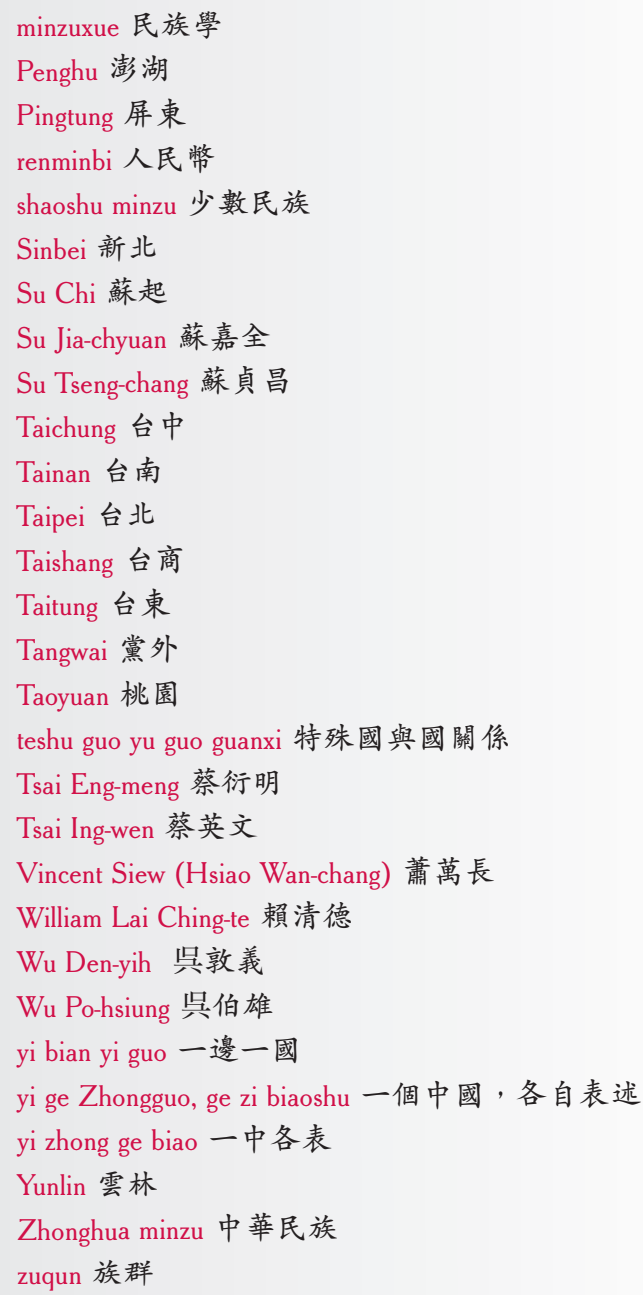

